\title{
Th.G. Sahama's (1910-1983) volcanological and mineralogical studies in Africa: Part I. Expeditions to the Virunga Volcanic Field and petrological- mineralogical studies on the Nyiragongo volcano
}

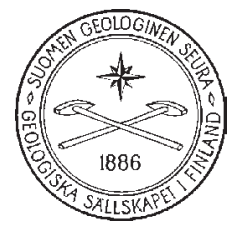

\author{
ILMARI HAAPALA \\ Department of Geosciences and Geography, P.O. Box 64, FI-00014 University of Helsinki, \\ Finland
}

\begin{abstract}
The alkaline lavas of Mt. Nyiragongo in the Virunga Volcanic Field (western branch of the East African Rift), as well as the granitic pegmatites and hydrothermal mineral deposits of eastern and southern Africa, were the main research topics of Professor Th.G. Sahama (University of Helsinki) during thirty years. During several expeditions 1952-1972 to the Virunga Field, Sahama and his team collected large amounts of samples from the foot plane, flank flows, caldera walls, and the lava lake of Mt Nyiragongo, which were studied in Helsinki University and in Brussels. The lavas turned out to be feldspar-free nephelinites, leucitites and melilitites containing as major constituents nepheline, leucite, melilite, kalsilite, and clinopyroxene in varying proportions. The Nyiragongo lavas are more alkaline than the other volcanics of the Virunga Field. Sahama and his team found and described six new silicate minerals from the Nyiragongo lavas: götzenite, combeite, kirschsteinite, trikalsilite, delhayelite, and andremeyerite, some of which locally represent the main constituents of the rocks. Sahama concluded that the Nyiragongo lavas crystallized from mantle-derived magmas without significant crustal contamination. The crustal magma chamber was layered, and the eruption started with melilite nephelinite (bergalite) magmas from the top of the chamber, followed by nepheline leucitite magmas and finally by melilite-leucite nephelinite ("nepheline-aggregate lava") melts. Sahama's studies aroused great international interest among petrologists and mineralogists, which has activated further systematic geochemical, mineralogical and isotopic studies in the area.
\end{abstract}

Corresponding author email: ilmari.haapala@helsinki.fi

\section{Introduction}

Professor, Academician Thure Georg Sahama (1910-1983; Sahlstein until 1936) dedicated his life to research in geological sciences: microtectonics, geochemistry, volcanology, and mineralogy (Neuvonen, 1985; Haapala 1985). He became interested in mineralogy as a school boy and studied geology and mineralogy under Professor Pentti Eskola (1883-1964) at the University of Helsinki. By the time he received his MA degree in 1934, he already had published a number of mineralogical and 
petrologic articles in international journals. His doctoral dissertation dealt with microtectonics of the granulites of Lapland. However, meeting Professor V.M. Goldschmidt (1888-1947) in 1935 in Gottingen turned his interest to geochemistry, a then new and rapidly evolving branch of geology. He built a modern geochemical laboratory, equipped with an optical spectrometer and $\mathrm{x}$-ray fluorescence spectrometer, in the Department of Geology, University of Helsinki, and published from 1936 to 1946 a number of high-standard geochemical studies on minerals and rocks of Finland. In 1946, he was appointed Professor of Geochemistry. His famous book Geokemia was published in Finnish the same year, and the English version Geochemisty, written together with Kalervo Rankama (19131995), appeared in 1950 (6th edition in 1968). In the late 1940 's, Sahama studied the thermochemistry and stabilities of olivine group and orthopyroxene group minerals at the Geophysical Laboratory, Carnegie Institution of Washington. After returning to Finland, he built thermochemical facilities in the Geochemical Laboratory to continue studies in this field. However, his remarkable expeditions to East and Central Africa in the 1950's turned his interest permanently to volcanology and mineralogy. The lavas and exotic mineral assemblages of the Nyiragongo volcano in the Virunga Volcanic Field in the Congo and Uganda, and the rare-mineral pegmatites of Mozambique and Rwanda were his main topics of interest, and largely through his studies these deposits came to be known to petrologists and mineralogists all over the world. From the Nyiragongo lavas, African pegmatites and hydrothermal deposits he, together with his coworkers, discovered and described thirteen new mineral species.

This is the first of two articles on Th.G. Sahama's volcanological and mineralogical studies in Africa. This article covers his expeditions to the Virunga Volcanic Field and petrological-mineralogical studies of the Nyiragongo volcano. The second article (Haapala, 2011) deals with his mineralogical studies of rare-mineral pegmatites and hydrothermal deposits throughout East, Central and southern Africa.

\section{Expeditions to the Virunga Volcanic Field in 1952-1972}

\subsection{Expedition 1952}

Sahama had a deep interest to study the mineralogy and thermochemistry of feldspathoids such as nepheline-kalsilite $(\mathrm{Na}, \mathrm{K}) \mathrm{AlSiO}_{4}$ and leucite $\mathrm{KAlSi}_{2} \mathrm{O}_{6}$ in his re-equipped laboratory. For his studies, he needed samples of these minerals with highly variable $\mathrm{Na} / \mathrm{K}$ ratio. During a visit to Edinburgh in 1951, he received from Professor Arthur Holmes (1890-1965) a sample of nepheline-bearing lava from the eastern slope of Mt. Nyiragongo, a volcano in North Kivu, in the border region between Uganda and Belgian Congo. The nepheline was separated and analysed, and contained more potassium than sodium in weight per percent (Sahama $\&$ Wiik, 1952). Sahama realized that the best way to get a broader range of mineral compositions was to sample them himself. Therefore, in autumn 1951, Sahama started, with the energy and thoroughness typical for him, to plan an expedition to this area, the Virunga Volcanic Field, part of the western branch of the East African rift system (Fig. 1a). He corresponded with directors and researchers from the Geological Surveys and other geological institutions working in the region. Financial aid was provided by the Finnish National Science Foundation, Finnish Academy of Science and Letters, Outokumpu Oy Foundation, and some other institutions and companies. As assistants he recruited Dr. Kaarlo Juhana Neuvonen (b. 1918) and Mr. Kai Hytönen (b. 1925), a student of geology. During this post-war period in Finland, it was necessary to make all travels as advantageously and economically as possible, and he did so using ship and train.

Sahama's group started the expedition with a train to Turku, then by ship to Stockholm, and by train through Denmark, Germany and Switzerland to Genoa in Italy. After a two week's voyage through the Suez Canal and Red Sea to the Indian Ocean, the travelers arrived in Mombasa, Kenya. From there they continued by train to Nairobi for a visit to the Geological Survey, and shopping for field gear and provisions for the expedition. They then proceeded 
further to Kampala in Uganda, where they arrived on July 8. They took rooms at Hotel Imperial and during the following days visited the Geological Survey for negotiations with Dr. K.A. Davies and Dr. Harris, and the Immigration Office in Entebbe. Sahama rented a car and hired a driver from an Indian transportation firm.

Field work on the western branch of the East African Rift Valley started on July 15 in the Fort Portal area, western Uganda. During three days, Sahama's group studied silica undersaturated lavas and tuffs of the area and collected specimens. Then they moved $100 \mathrm{~km}$ south to Kichawamba village and worked 11 days in that area. In detail they studied the rare mafurite (olivine-kalsilite rock) lava of Mafuru and, under the guidance of British geologist Barnes, the katungite lava (pyroxene-free melilitite) of Katunga. The next research subject was the Kisoro area, $100 \mathrm{~km}$ south of Kichawamba.

On August 6 the group moved further south to the Congo, and were amazed by the imposing volcanoes on both sides of the road. They had come to the Virunga (Birunga) Volcanic Field, where eight volcanoes rise over three kilometers in height and the two westernmost, Mt. Nyiragongo and Mt. Nyamuragira (or Nyamulagira), were active (Fig. 1b). The Virunga Volcanic Field forms part of the Virunga National Park (earlier named Albert National Park), formed already in 1925, because of its great diversity of habitats (steppes, savannas, lava plateaus, volcanoes, mountain forests, swamps, animals), and since 1979 it has been a World Heritage site.

Sahama's group was accommodated in a hotel in the town of Goma on the northern shore of Lake Kivu, and during the following days they studied the lava flows and small volcanoes of the area. Access was easy where lava flows from Nyiragongo and Nyamuragira volcanoes had flown across the roads, but they also sampled the lower slopes of Mt. Nyiragongo. On August 12-14, the researchers drove from Goma through Kabale and Masaka back to Kampala. Sahama visited again the Geological Survey and negotiated with Dr. Davies about a research trip to Northeast Uganda.

In eastern Uganda, Sahama's team studied the

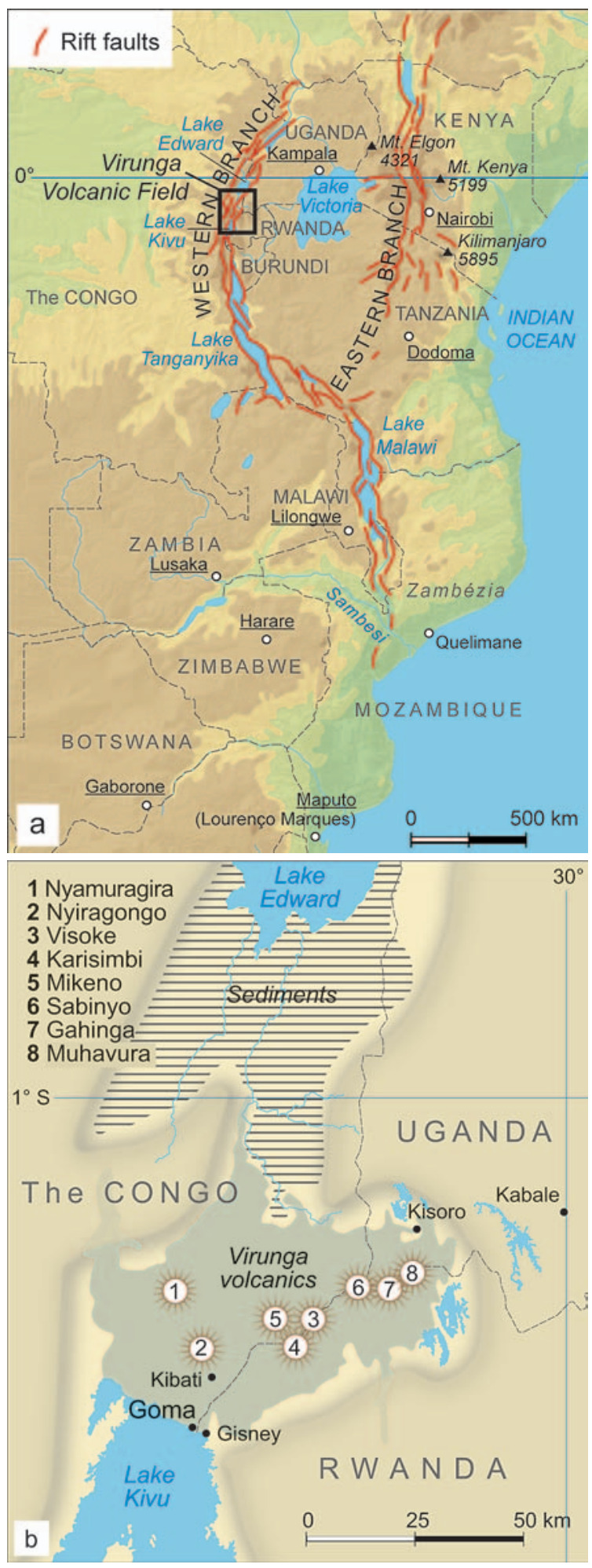

Fig. 1. (a) Location of the Virunga Volcanic Field in the western branch of the East African Rift System; (b) geological map of the Virunga Volcanic Field, modified from Sahama (1978). 
base and lower slopes of the huge Mt. Elgon volcano and the smaller Tororo mountain. In the Karamoja province, the travelers studied and sampled the volcanoes of Moroto (3084 m) and Toror Hills, and Hytönen filmed folk dances and festivals of the villagers.

Before returning to Finland, the group studied and sampled flanks of Mt. Kenya (5200 m). Sahama and Hytönen then made a taxi trip to Tanganyika (Tanzania) collecting specimens from the lower slopes of Mt. Meru (4566 m), visiting the huge Ngorongoro crater (diameter 16-19 km, depth 600 $\mathrm{m})$ and hiking on the southeastern slopes of $\mathrm{Mt}$. Kilimanjaro.

As there were still enough funds remaining, Sahama, Neuvonen and Hytönen returned by air, using different routes. Sahama landed in Helsinki on October 10, four months after the start of the expedition.

\subsection{Laboratory research in Finland in autumn 1952 - spring 1954}

After arriving back in Helsinki, Sahama and his assistants started their effective research investigations. The Geochemical Laboratory changed to a Mineralogical Laboratory, where Sahama and his assistants studied from early morning to late night the mineralogy and petrology of the African lavas. An important research tool was the $\mathrm{x}$-ray diffractometer that was purchased in 1952 - this Philips Norelco diffractometer is now displayed in the Historical Museum of the university. Soon the first research results began to appear. Later the laboratory was equipped with an infrared spectrometer, electron microscope and scanning electron microscope. In 1953, Sahama published in the series of the Finnish Academy of Science, two articles on the mineralogy and petrology, and nepheline-kalsilite exsolution in alkaline lavas of the Mt. Nyiragongo area (Sahama, 1953a,b), and in 1954 an article appeared on the mineralogy of the mafurite lava (Sahama, 1954). Neuvonen's paper on the katungite lava was published in 1956 . It was clear that a very important research topic was found, and Sahama started to plan a new expedition to the Mt. Nyiragongo area in Belgian Congo.

\subsection{Expedition 1954}

For the new expedition to the Virunga Volcanic Field, Sahama received financial aid from the Finnish National Science Foundation and some other sources. In winter 1953-1954, Sahama corresponded with representatives of the geological institutions of Belgium and the Congo. Support was promised in the form of accommodation, transport, labor, and scientific experts for the new expedition.

Travel to the Virunga Volcanic Field was again made mainly by ship and train, but using different routes than in 1952. Sahama and Hytönen started the journey on June 6 by ship from Helsinki to Stockholm, then by train via Copenhagen and Gottingen to Giessen (a visit to Leitz microscope and camera factories in Wetzlar), on to Brussels (meeting geologists from the Belgian Central African Museum, and Professor M-E. Denaeyer at the University of Brussels), then to Antwerp. From Antwerp started a three weeks voyage by freighter to Matadi at the mouth of the broad Congo River on the Atlantic coast of the Congo, where they landed on July 14. Sahama and Hytönen continued by train to Leopoldville (Kinshasa), where they visited the well-equipped Geological Survey and negotiated with Director F. Corin, and then by plane to Bujumbura, the capital of Burundi, and further to Bukavu (the Congo) on the southern shore of Lake Kivu. There the travelers visited the Institut Reserche Scientifique Afrique Central (IRSAC) and the geological research institute. Sahama's team received for their field work a pick-up truck, driver and two young assistants. On July 27, they finally drove through Goma, heading north to Rumangabo in the Virunga Volcanic Field.

The first research topic was a small, $85 \mathrm{~m}$ high volcano Mihaga, formed as a result of an eruption in February-May, 1954, in the valley between Mt. Nyiragongo and Mt. Nyamuragira. Samples were taken from the still warm lava. At the end of July, Sahama and Hytönen moved to the Virunga $\mathrm{Na}$ - 
tional Park's field station in Kibati, about $15 \mathrm{~km}$ north of Goma and close to Mt. Nyiragongo. In the nighttime, light from the bubbling and glowing lava lake in the crater was reflected from the sky. Sahama and Hytönen mapped different lava flows from an area of about $10 \times 10 \mathrm{~km}$ south of the foothills of Mt. Nyiragongo as well as parts of Nyiragongo's East side and the parasitic craters Shaheru (southern flank) and Baruta (northern flank) (Fig. 2). The relative ages of the different lava flows were estimated from the type and amount of vegetation.

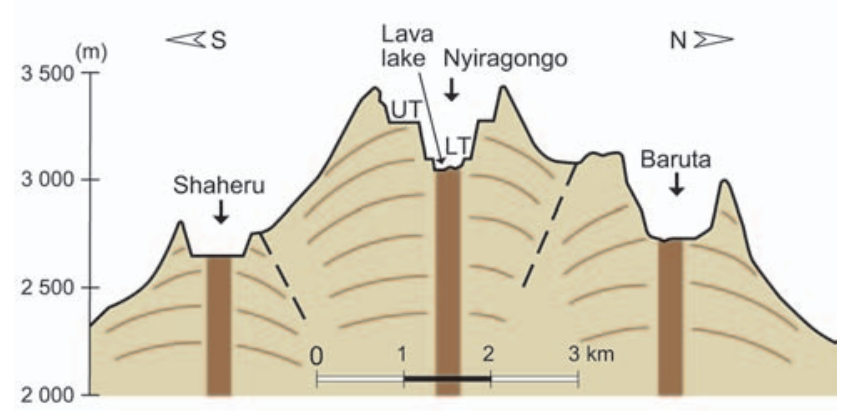

Fig. 2. South-north cross section of the Nyiragongo volcano through the Shaheru, Nyiragongo and Baruta craters (Sahama, 1962). The Nyiragongo crater was in summer 1959 about 1100 meters in diameter, with a $200 \mathrm{~m}$ wide upper terrace (UT) at a depth of 160-185 m, a lower terrace (LT) at $200 \mathrm{~m}$ deeper, and at the bottom a molten lava lake.

Beginning August 10, the group had the services of a geological guide in Mr. André Meyer from the Geologial Survey of Congo. Meyer was familiar with the geology of the area, and under his guidance the group made a five day trip to the Nyiragongo main crater and two parasitic craters (Fig. 3). The trip started with climbing from the southern margin of the volcano at $1900 \mathrm{~m}$ to a place suitable for camping (Camp des Bruyères) at $3000 \mathrm{~m}$, and the next day was spent studying the extinct parasitic crater Shaheru. On the third day, the group climbed to the southern rim of the Nyiragongo main crater at $3470 \mathrm{~m}$. Samples were collected and the crater and the lava lake were photographed and filmed, then the trip continued to the northern margin of the crater and down to level ground on the southern side of the Baruta crater where the group camped for two nights. On the fourth day, the group moved to the northern side of the crater where it was possible to walk into the crater itself. At the bottom of the Baruta crater grew trees and bushes, and there was also a watering hole, a necessity for wild animals. On the fifth day, the group headed back, blazing a trail with billhooks through the forest, down to Kibuati.

A funny side story is linked to the Mt. Nyiragongo safari. During the visit to the Leitz factory in June, Sahama and Hytönen had received as gifts high-quality loupes with leather cases, but Hytönen lost his loupe somewhere on Mt. Nyiragongo. A few years later, the loupe and leather case unexpectedly appeared on Sahama's table in the University of Helsinki. The loupe had been found when preparations were made for the safari of Belgium's ex-king Leopold III on the Camp des Bruyers camping place in 1956, and the guard of the National Park remembered that two years earlier the two Finnish geologists had had such loupes. He did not remember their names, but because the name Leitz was written on the lens, it was mailed to Leitz in Germany. Detective studies at Leitz finally brought to light the names of the neglectful Finnish geologists, and the loupe was mailed to Sahama.

At the end of August in Goma, Sahama and Hytönen met Professor Denaeyer, who had come from Brussels to study the geological structure and the lavas of the Virunga Volcanic Field, and Swiss Professor A. Heim, who led a scientific research group. Under Sahama's guidance they made an excursion to the lower slopes of Mt. Nyiragongo.

On September 19, Sahama and Hytönen returned to Entebbe. With a taxi they made a few days excursion to Karamoja in northeastern Uganda. Hytönen had made his Master's thesis on the petrology of the alkaline volcanic rocks of that area, and now they made additional studies and collected samples from the Toror Hills area for his doctoral thesis. In the field, they met British geologist C.G.B. Du Bois and his wife. Du Bois was studying the general geology, structure, ages, and petrogenesis of the Toror Hills area. Because Hytönen's interest was in the petrology and mineralogy of the alkaline lavas, their studies complemented each other. In Kotido, 


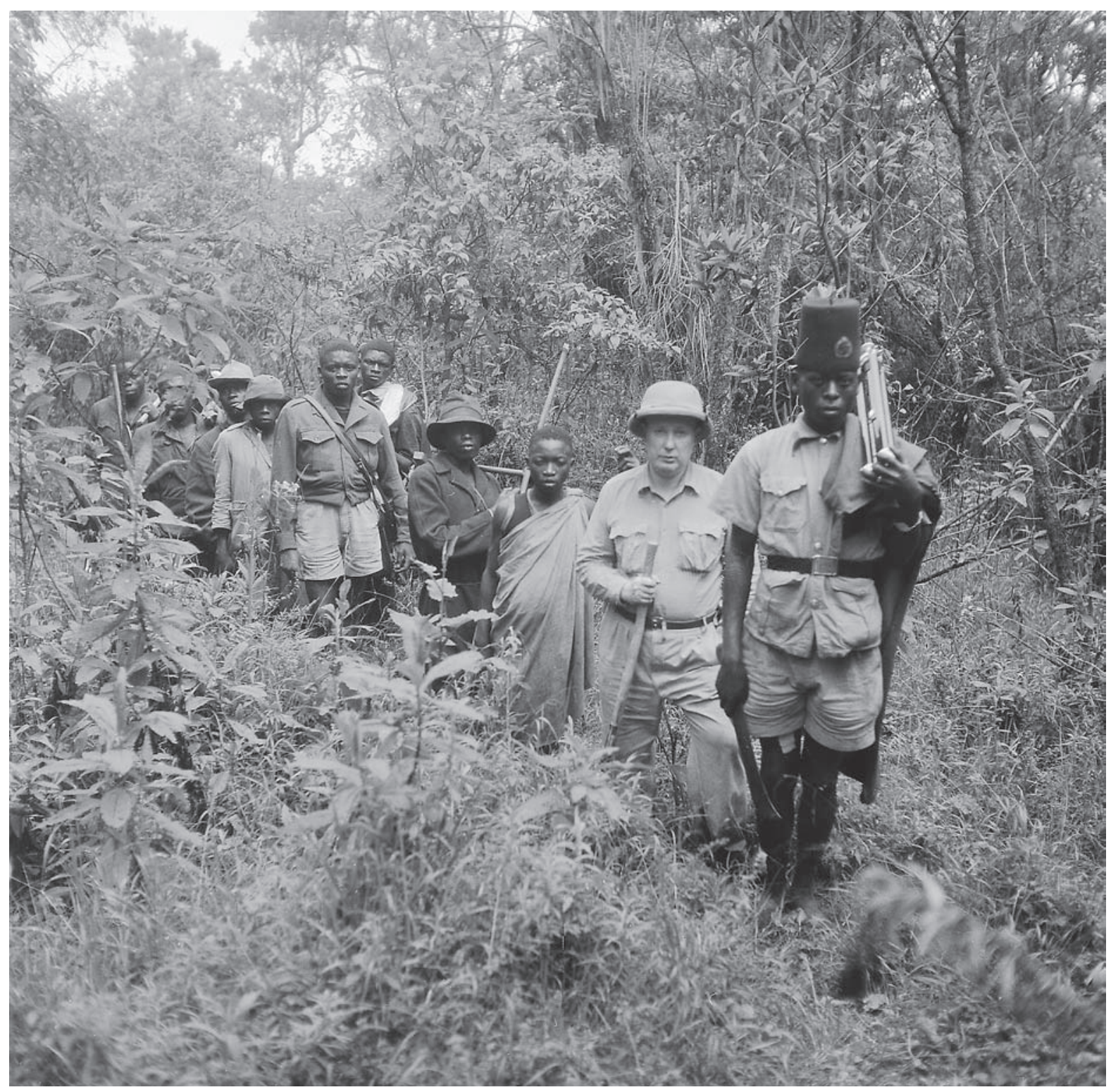

Fig. 3. Th.G. Sahama's expedition on the lower, eastern slopes of Mt. Nyiragongo in August 1954. Sahama second from the right. Photo Kai Hytönen (Haapala, 2009).

near Toror Hills, Sahama and Hytönen accidentally found themselves in the middle of a bustling market at the start of a public festival. Hytönen had the opportunity to film from a short distance a wild war dance. They returned to Entebbe and Lake Victoria Hotel on September 27.

Sahama and Hytönen returned to Finland by air via London. They visited Cambridge, and met there Sahama's long-time friend Professor C.E. Tilley and a young feldspar specialist, Dr. Joseph Smith.
They arrived in Helsinki in early October.

Back at the University of Helsinki, Sahama and Hytönen went again with enthusiasm into the laboratory research of the lava samples. As before, the main interest was in the mineralogy and petrology of the lavas, and the results were extremely interesting and scientifically important, as will be described later. A plaster model was constructed of Mt. Nyiragongo, where different lava flows were marked with different colors. In addition to other 
studies, Hytönen prepared his thesis on the petrology and mineralogy of volcanic rocks of Karamoja, northeastern Uganda (Hytönen, 1959).

The expeditions to Africa became visible in the interior of Sahama's laboratory. On the floor of Sahama's working room was a skin of a lion, on the wall a skin of leopard and a big python, two spears, a shield, and maps. Boxes, drawers and shelves were full of bottles, pots and cigar boxes containing mineral fractions and powders, and on the floor of the preparation room there was a growing heap of numbered rock and mineral samples from Mt. Nyiragongo and other African mineral localities.

\subsection{Later expeditions}

The collaboration with André Mayer was strengthened when his office was moved to Goma with a duty to make observations on the volcanic activity and study the volcanoes of the Virunga Field. He sent samples to Sahama for laboratory studies, and twice he visited Sahama in Helsinki. During the first visit in late autumn 1956, he received a telegram from the Governor of Belgian Congo telling of a new eruption that had started on the northern slope of Mt. Nyamuragira.

Meyer stopped working in Finland immediately and hurried to Virunga, and one week later Sahama was also there. New research material was collected, particularly from Baruta. During Meyer's second visit to Helsinki in summer 1957, the two scientists prepared the final research report of Mt. Nyiragongo.

In 1958 Sahama participated, together with A. Meyer, in the Mt. Nyiragongo expedition led by Professor Ivan De Megneé. The participants camped on the upper terrace of the crater, and samples were collected from different parts of the main crater (Figs. 4-5). By using a steel wire cable, some researchers succeeded in descending for the first time down into the inner crater. In 1959, a large expedition was sent to Nyiragongo under the leadership of Professor Pierre Evrard. The expedition descended to the lava lake on the bottom of the crater (lower terrace), where temperatures were measured and samples taken of the molten lava (Fig.6). A. Meyer collected specimens and sent duplicates of them to Sahama in Helsinki, but they arrived virtually two years after their collection.

The Congo, then a colony of Belgium, declared independence on June 30, 1960, under the name Republic of Congo. The official name switched to Democratic Republic of the Congo in 1965-1971, in 1971-1997 Zaire, and since then back to Democratic Republic of the Congo. There were several conflicts and bloody wars in the new state, causing most of the European population to flee the country. The connections to the Kivu district were disrupted, and also André Meyer had to leave Goma because of the political disturbances. Meyer and Sahama had, however, succeeded in making many accurate geological observations and large

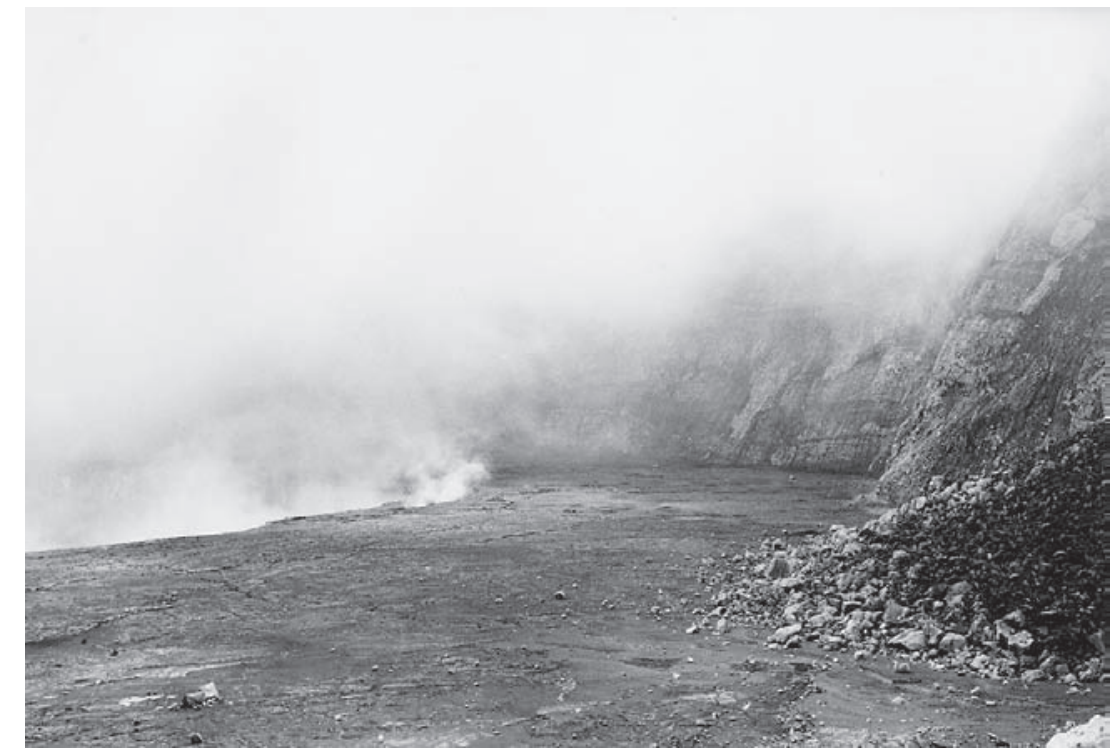

Fig. 4. The upper terrace of the Nyiragongo crater in 1958. The tents of the expedition are visible at the lower left corner of the photo. The crater wall on the right is about 170 meters high. The inner crater and vapors rising from the lava lake on the right. Photo E. Schultthess (Haapala, 2009). 


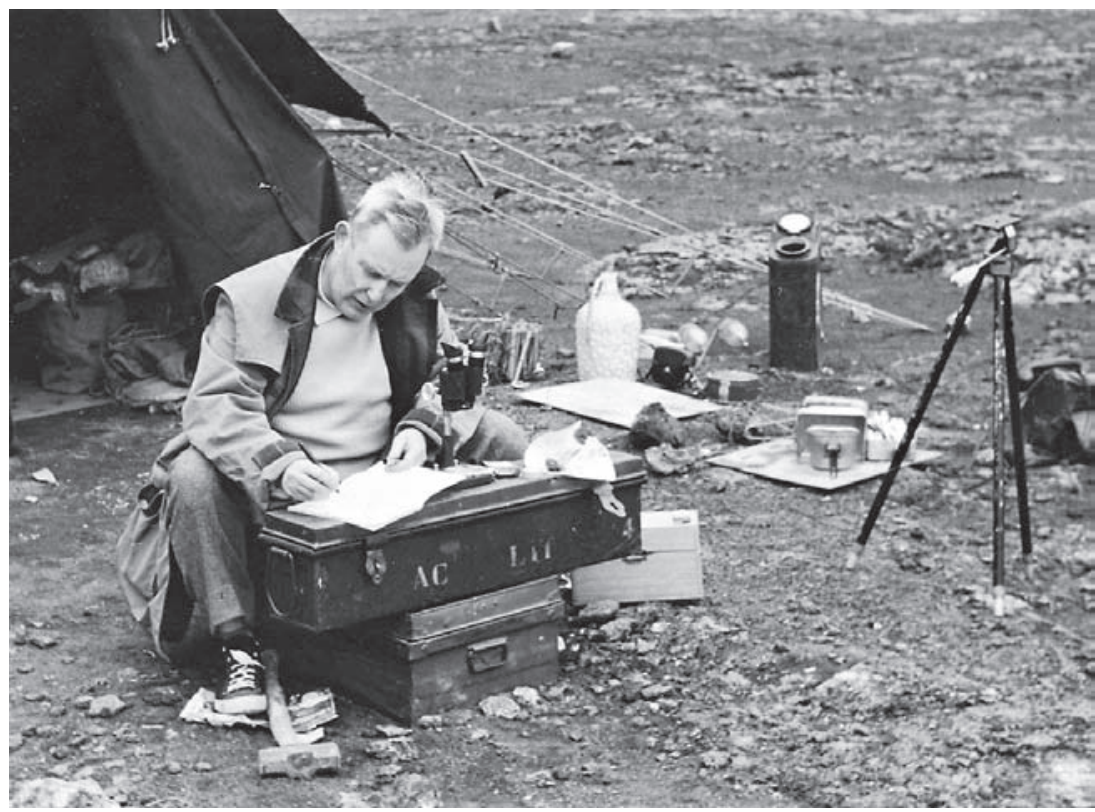

Fig. 5. Th.G. Sahama writing observations on the upper terrace of the Nyiragongo crater in 1958. Photo André Meyer (Haapala, 2009).

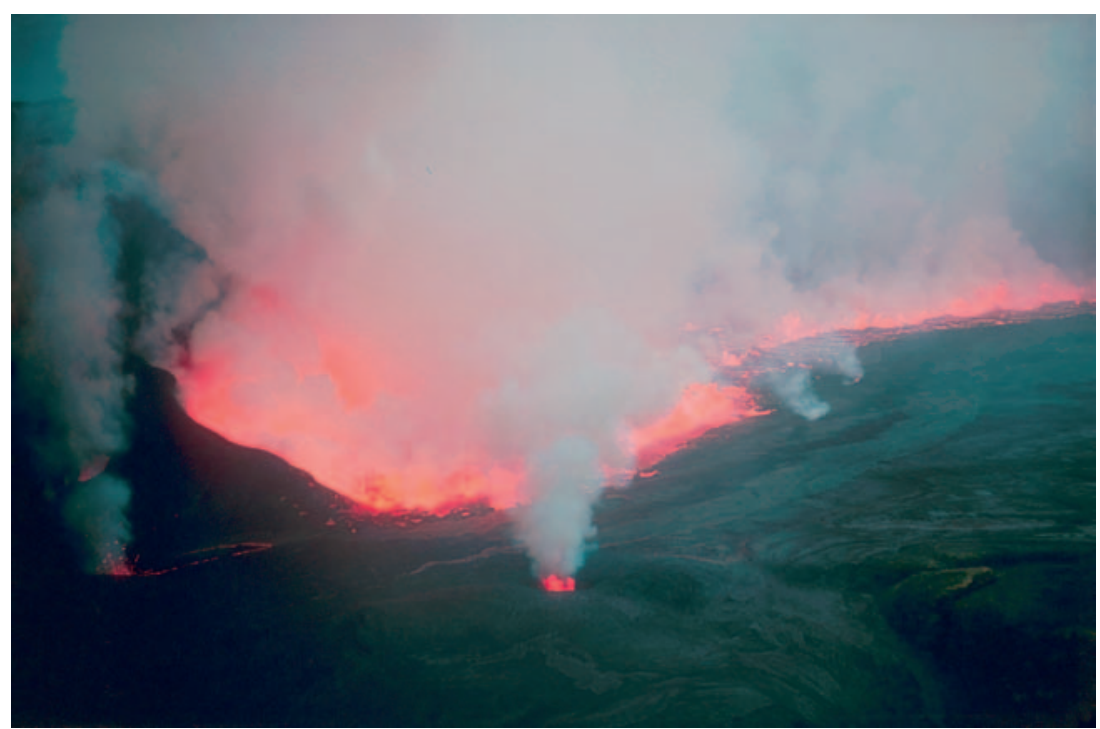

Fig. 6. The lava lake at the bottom of the Nyiragongo caldera in 1959. Using steel wire cables the researchers descended to the bottom of the crater and took samples from the molten lava. The photo was taken from the edge of the inner crater. Photo Th.G. Sahama (Haapala, 2009). collections of rock samples. Thus active laboratory research continued in Finland and Belgium. Sahama's collaboration with Meyer continued until the death of Meyer (1965). Since the late 1950 's, their research was focused more into general volcanology and igneous petrology than mineralogy.

The lava lake of the Mt. Nyiragongo had stayed tens of years fluid but relatively stable. In 1964, however, the surface of the lava lake started to rise, and in 1972 lava flowed to the upper terrace, after which the lava lake again sank. In August 1972, a new expedition was made to Mt. Nyiragongo under the lead of Professor Haroun Tazieff from Paris, and the 62 years old volcanologist Sahama participated in it. The group descended to the new lower terrace of the crater, and some participants succeeded to go down to the active bottom of the crater. This was the last time Sahama was to visit Mt. Nyira-gongo.

In January 1977, an unexpectedly violent eruption of Nyiragongo took place. The crater walls fractured, the terraces collapsed, and the lava lake drained away. The fluid lava flowed down the slopes at a speed of up to $100 \mathrm{~km}$ per hour overwhelming villages and killing at least 70 people. The next violent eruption took place in January 2002. A $13 \mathrm{~km}$ fracture 
opened on the southern flank of the volcano, the lava poured out from three spatter cones and flowed as a 200 to $1000 \mathrm{~m}$ wide stream to the city of Goma reaching Lake Kivu. About 400000 people were evacuated to Rwanda, the city was largely destroyed, 120000 people lost their homes, and at least 45 people were killed. These natural catastrophes are, however, minor compared to the cruelties and havoc created by the people in the region in 1994 and later.

\section{Minerals of the Mt. Nyiragongo lavas}

\subsection{Feldspathoids}

The primary goal of Sahama's expedition to Uganda and Belgian Congo in 1952 was to find potassium-rich nepheline and other feldspathoids for mineralogical and thermochemical studies. At that time, kalsilite, the potassium member of the nepheline-kalsite system $(\mathrm{Na}, \mathrm{K}) \mathrm{AlSiO}_{4}$, was known in small amounts only from the Bunyaruguru volcanic field in Uganda (Holmes, 1942a; Bannister \& Hey, 1942) and from San Venanzo in Italy (Holmes, 1942b; Bannister et al., 1953). From the samples collected during Sahama's first expedition, kalsilite was found in samples from the mafurite of the
Mafuru caldera in the Bunyaruguru field (the original kalsilite locality of Holmes) (Sahama, 1954), from a katungite flow in Katunga, western Uganda (Neuvonen, 1956), and from a porphyritic nephelinite flow on the outer eastern slope of the Nyiragongo volcano (Sahama, 1953b). Subsequent studies showed that kalsilite is one of the main constituents in considerable part of the lavas of Mt. Nyiragongo.

Sahama and his team studied thoroughly the mineralogy of the nepheline-kalsilite system of Mt.Nyiragongo; its mode of occurrence and exsolution textures (Sahama 1953b, 1957, 1960), and its optical and $\mathrm{x}$-ray crystallography as well as $\mathrm{x}$-ray methods to determine the composition of nepheline and kalsilite (Sahama et al., 1956; Smith \& Sahama, 1954). Whereas kalsilite occurs in the lavas of the Bunyarunguru field only in small amounts in the matrix, in the Nyiragongo nephelinites and melilitites it occurs both as phenocrysts and in the groundmass. Perthitic exsolution textures with nepheline (crypto-, micro- and macroperthite, kalsilite as host) is characteristic, but nepheline also occurs as separate grains or as a narrow zone at the margins of the kalsilite phenocrysts (Fig. 7).

In 1962, Sahama published an interesting study of possible order-disorder transitions in natural nepheline. To test if varying $\mathrm{Si}-\mathrm{Al}$ ordering similar

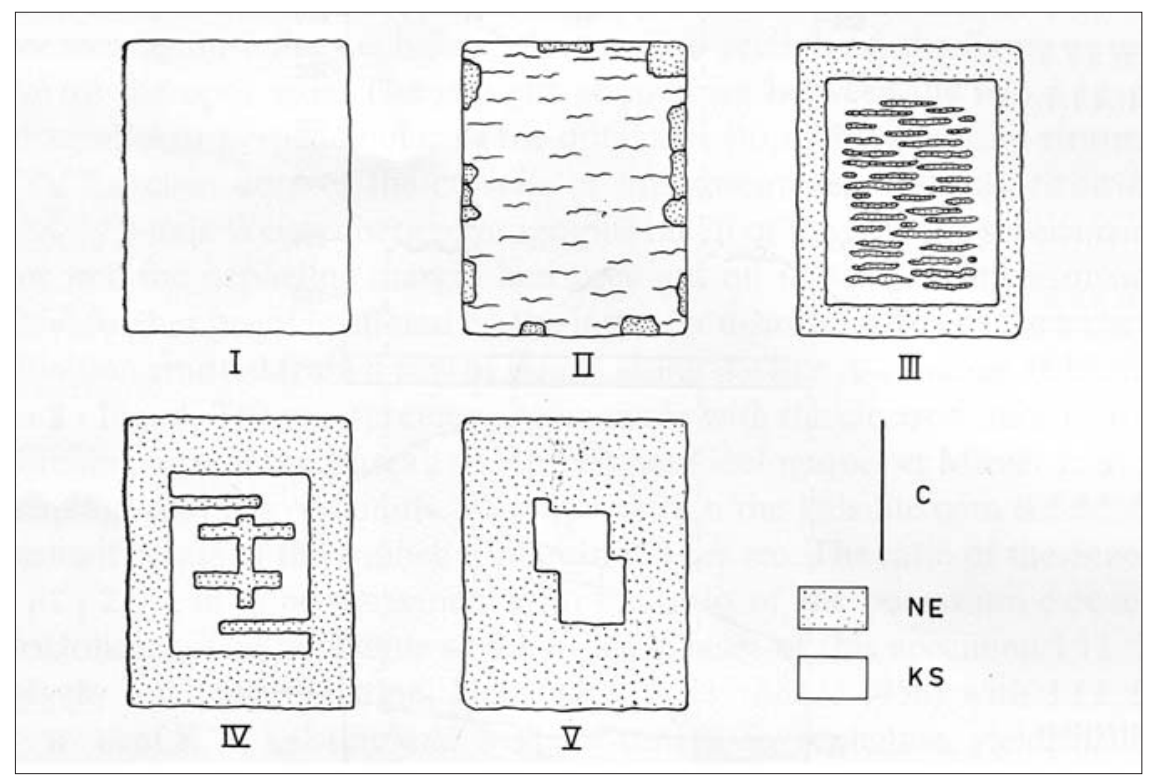

Fig. 7. Sahama's model of the exsolution phenomena in the complex nepheline-kalsilie phenocrysts in the Nyiragongo lavas. I, a homogeneous hightemperature phase with about $70 \%$ kalsilite in solid solution; II, beginning stages of exsolution; III, a coarsely perthitic kalsilite core surrounded by a narrow zone of nepheline-free kalsilite and a continuous margin of homogeneous nepheline; IV, a core of homogeneous kalsilite (with a few nepheline lamellae) surrounded by a thick nepheline margin; $\mathrm{V}$, a homogeneous kalsilite core surrounded by a thick nepheline margin (Sahama, 1960). 
to that in the oxygen tetrahedra of alkali feldspar exists also in nepheline, Sahama made crystal optical and heating tests on 34 nephelines representing different geological environments. Because the hexagonal symmetry of nepheline does not allow the use of any methods based on optical extinction angles or optic axial angles, nor on variations in the angles between the crystallographic axes, as in alkali feldspars, Sahama (1962a) studied the variation of birefringence at $20-900^{\circ} \mathrm{C}$ as a possible indication of the ordering state. He found that at room temperature nepheline of plutonic rocks has higher birefringence than nepheline of volcanic rocks. He also detected small differences in the thermal expansion of plutonic and volcanic nephelines. Sahama concluded that the variations in birefringence may represent varying degree of ordering in the distribution of $\mathrm{Si}$ and $\mathrm{Al}$ atoms in the oxygen tetrahedra, the plutonic nephelines representing the more ordered crystal structure. Several crystal structure studies (e.g. Dollase \& Peacor, 1970; Simmons \& Peacor, 1972 and references therein) have supported Sahama's model, whereas others (e.g. Tait et al., 2003 and references therein) have suggested that nepheline exhibits high $\mathrm{Al}-\mathrm{Si}$ ordering irrespective of the temperature of origin.

Sahama also used other minerals of the Nyiragongo lavas in general mineralogical studies of rock-forming and rare minerals. Good examples are the studies on the mineralogical properties of calcium-bearing magnesium-iron olivines (Sahama \& Hytönen, 1958), and on the compositions of clinopyroxene and melilite of the Nyiragongo rocks (Sahama, 1976). The latter study was based on large amounts of electron probe microanalyses that Sahama had himself made in the Carnegie Institution of Washington's Geophysical Laboratory. Papers on chemical composition (Sahama, 1967), infrared absorption (Sahama \& Lehtinen, 1968a), and crystallography (Sahama, 1975) of melilite were based largely on material from the Nyiragongo lavas.

\subsection{New minerals}

The alkalic lavas of Mt. Nyiragongo were exceptional not only in chemical composition but also in mineral composition. Sahama and his collaborators described from the lavas six new mineral species (Table 1).

Among the specimens collected by Sahama and Hytönen during the 1954 expedition, one sample taken from a boulder on the north-eastern inner wall of the Shaheru crater proved to be a real mineralogical treasure. From this holocrystalline, mineralogically complex nephelinite sample, four new silicate mineral species was found (Table 1): combeite $\mathrm{Na}_{2} \mathrm{Ca}_{2} \mathrm{Si}_{3} \mathrm{O}_{9}$ and götzenite $\mathrm{Na}_{4} \mathrm{Ca}_{10} \mathrm{Ti}_{2}$ $\left(\mathrm{Si}_{2} \mathrm{O}_{7}\right)_{4} \mathrm{~F}_{8}$ (Sahama \& Hytönen, 1957a), kirschsteinite $\mathrm{CaFeSiO}_{4}$ (Sahama \& Hytönen, 1957b), and delhayelite $(\mathrm{Na}, \mathrm{K})_{10} \mathrm{Ca}_{5} \mathrm{Al}_{6} \mathrm{Si}_{32} \mathrm{O}_{80}\left(\mathrm{Cl}_{2}, \mathrm{~F}_{2}, \mathrm{SO}_{4}\right)_{3}$ $18 \mathrm{H}_{2} \mathrm{O}$ (Sahama \& Hytönen, 1959). Kirschsteini-

Table 1. New mineral species discovered and described by Th.G. Sahama and co-workers from the lavas of Mt. Nyiragongo.

Combeite $\quad \mathrm{Na}_{2} \mathrm{Ca}_{2} \mathrm{Si}_{3} \mathrm{O}_{9}$, rhombohedral. Named after A.D. Combe (Geol. Survey of Uganda).

Sahama, Th.G. \& Hytönen, K. (1957a)

Götzenite $\quad \mathrm{Na}_{4} \mathrm{Ca}_{10} \mathrm{Ti}_{2}\left(\mathrm{Si}_{2} \mathrm{O} 7\right)_{4} \mathrm{~F}_{8}$, triclinic. Named after count G.A. von Götzen (who ascended Mt. Nyiragongo in 1894).

Sahama, Th.G. \& Hytönen, K. (1957a)

Kirschsteinite $\mathrm{CaFeSiO}_{4}$, orthorhombic. Named after F. Kirschstein (studied the volcanoes of the Kivu area). Sahama, Th.G. \& Hytönen, K. (1957b)

Trikalsilite $\quad(\mathrm{K}, \mathrm{Na}) \mathrm{AlSiO}_{4}$, hexagonal. Named after crystal structure (cf. kalsilite) Sahama, Th.G. \& Smith, J.V. (1957).

Delhayelite $\quad(\mathrm{Na}, \mathrm{K})_{10} \mathrm{Ca}_{5} \mathrm{Al}_{6} \mathrm{Si}_{32} \mathrm{O}_{80}\left(\mathrm{Cl}_{2}, \mathrm{~F}_{2}, \mathrm{SO}_{4}\right)_{3} 18 \mathrm{H}_{2} \mathrm{O}$, orthorhombic.

Named after geologist F. Delhaye. Sahama, Th.G. \& Hytönen, K. (1959)

Andremeyerite $\mathrm{BaFe}_{2} \mathrm{Si}_{2} \mathrm{O}_{7}$, monoclinic. Named after geologist A. Meyer. Sahama, Th.G., Siivola, J. \& Rehtijärvi, P. (1973) 
te, götzenite and combeite are among the main constituents of the rock, which Sahama (1961) called kirschsteinite-melilite-sodalite nephelinite. Sahama and his collaborators published pertinent mineralogical data (mode of occurrence, chemical analysis, $\mathrm{x}$-ray crystallography, physical and optical properties) of the new minerals.

A new barium-iron silicate, which Sahama et al. (1973) named andremeyerite, was found in vesicle fillings in a sample of melilite-leucite-nephelinite collected by Sahama and Meyer in 1958 from the rim of the Nyiragongo main crater. Trikalsilite, a new mineral with the formula $(\mathrm{K}, \mathrm{Na}) \mathrm{Al} \mathrm{SiO}_{4}$, was found as parallel intergrowths in the kalsilite-nepheline microperthite in the Kabfumu lava flow between Mt. Mikeno and Mt. Nyiragongo (Sahama \& Smith, 1957).

\section{Petrology of the Mt. Nyiragongo lavas}

\subsection{Petrography}

Soon after the first expedition, Sahama (1953a) published a petrographic study of a nephelineaggregate lava flow, later named Kabfumu flow, extending from the upper slopes of Mt. Nyiragongo down to the lava plane southeast of the volcano. Samples had been collected from the levels of 2950$3000 \mathrm{~m}$ (upper slope) and along the GomaRutchuru road at $2000 \mathrm{~m}$ (lava plane). The original sample that Sahama had obtained from Professor Holmes was probably derived from this flow. The lava contained about $80 \%$ aphanitic groundmass, with phenocrysts of nepheline and small amounts of melilite, leucite and clinopyroxene. Sahama also published chemical analyses of two lava samples and their groundmass, as well as six new analyses of nepheline. The nepheline contained about 40 mole $\% \mathrm{KAlSiO}_{4}$ (Sahama, 1953a).

After the geological mapping during the 1954 expedition, Sahama had much more research material from the different lava flows, and the collaboration with André Meyer also increased the collection markedly. In the monograph Study of the volcano Nyiragongo - Progress report, Sahama and Meyer (1958) gave a geological overview of the Virunga Volcanic Field and described in detail the structure of the volcano as well as the petrographic characteristics and chemical compositions of different lava flows. The Nyiragongo lavas are extremely alkaline nephelinites, leucitites and melilitites (bergalites). Subsequent studies (Sahama, 1961, 1962b, 1968a, 1968b, 1973, 1978) deepened the petrologic picture.

In 1961 Sahama described evidence of recrystallization in the lavas, especially at the phenocryst boundaries, and mineral replacement textures (e.g. replacement of melilite by kirschsteinite). He regarded these phenomena as an evidence of retrogressive intravolcanic thermal metamorphism and suggested a name ipnism for it. This term has not been adopted in the common geological literature. Some Nyiragongo lavas contain partially fused granitic xenoliths, fragments from the underlying Precambrian basement. The alkali feldspars of the xenoliths are homogeneous, nonperthitic under the microscope, and x-ray studies showed them to plot on the analbite-high sanidine join, indicating that the feldspars were completely disordered due to heating in the melilite nephelinite magma. The xenoliths had narrow reaction rims against the lava containing sillimanite, cordierite, spinel, and sanidine, indicating minor reactions between the xenoliths and the magma (Lehtinen \& Sahama, 1982).

\subsection{Geochemistry and petrogenesis}

In the article Geochemical evolution of the Nyiragongo magma, Sahama (1973) compared, on the basis of 264 representative chemical analyses from different sources, the Nyiragongo lavas to the lavas of $\mathrm{Mt}$. Nyamuragira and to the mainly basaltic lavas of South Kivu area. The rocks were classified by plotting their normative compositions (Rittmann, 1973) into the Streckeisen (1967) diagrams for volcanic rocks. The majority of the Nyiragongo lavas plot into the field of foidites proper, some into the field of phonolitic to tephritic foidites. The 
Nyamuragira volcanics plot into a broad field extending from alkali basalts to tephrites and phonolites. The volcanics of the South Kivu province plot into fields of basalts and trachytes. The average contents of $\mathrm{Na}_{2} \mathrm{O}+\mathrm{K}_{2} \mathrm{O}$ are 11.0, 6.3 and 3.6 wt. \% in the Nyiragongo lavas, Nyamuragira lavas and South Kivu basalts, respectively, and the corresponding $\mathrm{K}_{2} \mathrm{O} / \mathrm{Na}_{2} \mathrm{O}$ ratios are 1.0, 0.9 and 0.3 . In geochemical variation diagrams, the three lava groups show different trends. Sahama interpreted that the lavas of Nyiragongo, Nyamuragira and South Kivu represent three different, mantle-derived magma types, and are not members of the same comagmatic series. From variation diagrams and mineral compositions he concluded, that simple extraction of olivine, clinopyroxene and plagioclase cannot produce the Nyamuragira magma from the South Kivu basalt magma nor the Nyiragongo magma from the Nyamuragira magma (Sahama, 1973).

In the monograph The Nyiragongo main cone, Sahama (1978) concluded, from the succession of different eruptive phases in the Nyiragongo crater walls, that the eruption sequence started with a gascharged and carbonated nepheline melilitite (bergalite) melt, which at that time obviously represented the top portion of the magma chamber. It was followed by a nepheline leucitite melt and finally by a leucite nephelinite melt. The carbonated, gas-charged nature of the nepheline melilitite melt was inferred from the presence of fine-grained pyroclastic interlayers (indicating explosive activity) and the occurrence of calcite in the groundmass and vesicle fillings. Sahama suggested that magmatic $\mathrm{CO}_{2}$-bearing gases rich in alkalis and calcium (possibly as carbonate compounds, Sahama, 1968a) were concentrated along feeder channels into the top parts of the Nyiragongo magma reservoir.

Although he regarded gaseous transfer of alkalis as an important mechanism in differentiation of the Nyiragongo magma (Sahama, 1968a, 1973, 1978), he also realized the significance of fractional, gravitational differentiation. He noted that because leucite and nepheline have lower densities (2.47 and 2.66, respectively) than the lava lake melt (3.02), these minerals will float in the non-viscous melt and form phenocryst-rich leucitites and nephelinites (Sahama, 1978). He belived that this crystal flotation was largely responsible for the chemical and mineralogical composition of the nephelinites and leucitites stratigraphically above the nepheline melilitic pyroclastics and lava beds in the Nyiragongo caldera.

The relation of the magmas of the two active neighboring volcanoes, Nyamuragira and Nyiragongo, located only $15 \mathrm{~km}$ apart, was a problem to Sahama. The Nyiragongo volcano is situated at the intersection of several fracture zones, which provided feeding channels for the magmas and fluids. Sahama (1973) suggested that the enrichment of alkalies into the Nyiragongo magmas by gaseous transfer could be the reason for the difference between the Nyiragongo and Nyamuragira magmas. He estimated that an addition of some 6 wt. \% $(\mathrm{Na}, \mathrm{K})_{2} \mathrm{O}, 2$ wt. $\% \mathrm{CaO}$, and 1 wt. $\% \mathrm{P}_{2} \mathrm{O}_{5}$ to the average Nyamuragira magma would be sufficient to produce the main characteristics of the Nyiragongo magma. Sahama (1962b, 1968a, 1973) also considered the possibility that an effective gas transfer process in some instances might ultimately lead to development of carbonatite magma pockets in the magmatic system.

Sahama (1973) was of the opinion that the composition of the ascending mantle-derived Nyiragongo magma has not been markedly affected by crustal contamination. Although the lavas locally contain partially fused xenoliths of the Precambrian granite, their effect to the bulk composition of the volcanic system had been insignificant.

Since the 1960's, Mt. Nyiragongo and other volcanoes of the Virunga Volcanic Field have been studied by several other geoscientists. A detailed geological map of Thonnard and Denaeyer (1965) has served as a base for many studies. Volcanic activity was studied by Tazieff (1985 and references therein). New petrological, geochemical and isotopic studies on Nyiragongo and Nyamagira have been published (e.g. Vollmer et al., 1985; Hertogen et al., 1985; Demant et al., 1994; Platz et al., 2004; Chakrabarti et al., 2009). New eruptions in 1977 , 1982 and 2002 have provided additional fresh research material. 
Later systematic major and trace element studies - Sahama had only major component analyses available - have corroborated the essential aspects of Sahama's $(1973,1978)$ petrogenetic model. The significance of migrating magmatic $\mathrm{CO}_{2}$-rich fluids (gaseous transfer) in enrichment of the alkalies and incompatible trace elements in the Nyiragongo magmatic system has generally been accepted. However, several authors have emphasized the role of fractional crystallization and density-controlled separation of mineral crystals, especially clinopyroxene, in the early stages of the magmatic evolution (e.g. Hertogen et al., 1985; Demant et al., 1994), whereas Platz et al. (2004) explained that the parental pyroxene melilitite melt evolved to melilite nephelinite and melilitite by fractionation of leucite together with varying amounts of nepheline. Demant et al. (1994) presented a detailed eruption history of Mt. Nyiragongo, correlating the eruptions from Nyiragongo, Shaheru and Baruta craters, numerous other parasitic craters, fissure eruptions and flank flows with each other. They distinguished three phases in the growth of Nyiragongo, which was more detailed but largely corresponded to the evolution history presented by Sahama (1978). They also concluded that the crystallization and differentiation of the magmas took place in two magma chambers, situated at depths of $10-14 \mathrm{~km}$ and less than $1 \mathrm{~km}$.

Various isotopic ${ }^{87} \mathrm{Sr} /{ }^{86} \mathrm{Sr}$ and ${ }^{143} \mathrm{Nd} /{ }^{144} \mathrm{Nd}$ studies have confirmed the mantle origin of the Nyiragongo magmas. Among the lavas of the Virunga Volcanic Field, the Nyiragongo magmas are the least contaminated by crustal material (e.g. Rogers et al., 1998). Chakrabarti et al. (2009) concluded from $\mathrm{Nd}-\mathrm{Sr}-\mathrm{Pb}$ isotopic and geochemical studies that the Nyiragongo lavas were formed by a low degree partial melting of a garnet, clinopyroxene and phlogopite-bearing carbonated mantle at a great depth, whereas the Nyamuragira magmas originated by larger degrees of partial melting at comparatively shallower depths from mantle material that contained a recycled crustal component. They estimated that the melting took place at depths between 80 and $150 \mathrm{~km}$ in a heterogeneous mantle plume environment.

\section{Carbonatites of Africa}

Since the discovery of intrusive carbonatite rocks in South Norway (Brögger, 1921), their genesis primary magmatic, metasomatic or secondary magmatic involving melting of sedimentary carbonate rocks by intrusive magmas - has been a problem for petrologists. When eruption of carbonate lava was discovered in the volcano of Oldoinyo Lengai in Tanganyika (Tanzania) in 1960, the primary magmatic origin became evident (Dawson, 1962). This discovery led to a boom in carbonatite research in Africa and elsewhere. The Lengai lavas (lengaite or natrocarbonatite) are, however, unique in their composition - they consist largely of water-soluble $\mathrm{Na}-\mathrm{K}-\mathrm{Ca}$ carbonates - and have no terrestrial equivalents in the geological records. Sahama, who was studying the alkaline lavas of the Virunga volcanic field, get also interested in carbonatites and he made expeditions to several known carbonatite occurrences in Africa.

In 1961 Sahama studied the carbonatite lavas of Uganda (Nyakasura near Fort Portal and Moruangaperu at the Napak nephelinite-carbonatite volcanic complex in East Uganda), climbed with J.B. Dawson to the crater rim of Oldoinyo Lengai $(2890 \mathrm{~m})$ in the eastern branch of the East African Rift System, northernTanzania, made excursions to the Tundulu carbonatite ring complex in southern Nyasaland (Malawi) and to Derdeport, Spitzkop and Palabora carbonatite complexes in Transvaal, South Africa. In 1963, Sahama visited the Cretaceous Longonjo and Bailundo carbonatite complexes in Angola and studied their structure also from an airplane. He made a research visit to the Geological Survey of Tanzania in Dodoma, where he studied with the help of Dr. Peter Bowden the reports, samples and thin sections of Tanzanian carbonatites. In 1967, he again visited, with Oleg von Knorring, the Fort Portal carbonatite lavas in Uganda.

From Sahama's diaries, deposited at the Department of Geology, University of Helsinki, it appears that he was fascinated by the petrogenesis and mineralogy of carbonatites. He collected large amount of samples and wrote long descriptions of 
the African carbonatites in his diaries. However, he published only one general description in 1961 (in Finnish) of the African carbonatites and a short mineralogical paper with Dawson on the parawollastonite of Oldoinyo Lengai lava (Dawson \& Sahama, 1963). In addition, he shortly discussed the relations between alkalic lavas and carbonatites in one of his petrological papers of Mt. Nyiragongo (Sahama, 1962b). Apparently, Sahama realized that the carbonatites of Africa were already under active research, and he refrained from further involvement although maintaining a continued interest in their genesis.

\section{Acknowledgements}

I dedicate this article to late Professor Manuel Serrano Pinto (1936-2011), whose plan to edit a contributed book on the History of Geological Research in Africa, including articles on Th.G. Sahama's volcanological and mineralogical studies in Africa, collapsed because of his untimely death.

I am grateful to Professor Th.G. Sahama’s former assistants Dr. Kai Hytönen and Dr. Martti Lehtinen as well as to Dr. Peter Bowden, Dr. Hugh O’Brien and Mr. Reijo Alviola, who kindly reviewed the manuscript and made valuable suggestions. Alviola and Lehtinen also helped in finding photos for the article.

\section{References}

Bannister, F.A. \& Hey, M.H. 1942. Kalsilite, a polymorph of $\mathrm{KAlAiO}_{4}$, from Uganda. Mineralogical Magazine 26, $218-$ 224.

Bannister, F.A., Sahama, Th.G. \& Wiik, H.B. 1953. Kalsilite in venanzite from San Venanzo, Umbria, Italy. Mineralogical Magazine 30, 46-48.

Brögger, W.C. 1921. Eruptivegesteine des Kristianiagebietes. IV. Das Fengebiet in Telemarken, Norwegen. Norske Widenskabsselskabet i Kristiania Skrifter. I. Math.Naturwis. Klasse 9, 408 p.

Chakrabarti, R., Basu, A.R., Santo, A.P. Tedesco, D. \& Vaselli, O. 2009. Isotopic and geochemical evidence for a heterogenous mantle plume origin of the Virunga volcanics, Western Rift, East African Rift system. Chemical Geology 259, 273-289.

Dawson, J.B. 1962. Sodium carbonatite lavas from Oldoinyo Lengai, Tanganyika. Nature 195, 1075-1076.

Dawson, J.B. \& Sahama, Th.G. 1963. A note on parawollastonite from Oldoinyo Lengai, Tanganyika. Schweizerische Mineralogische und Petrologische Mitteilungen 43, 31-33.
Demant, A., Lestarde, P., Lubala, R.T., Kampunzu, A. \& Durrieux, J. 1994. Volcanological and petrological evolution of Nyiragongo volcano, Virunga volcanic field, Zaire. Bulletin of Volcanology 56, 47-61.

Dollase, W.A. \& Peacor, D.R. 1971. Si-Al ordering in nepheline. Contributions to Mineralogy and Petrology 30, 129-134.

Haapala, I. 1985. Memorial of Thure Georg Sahama, October 14, 1910-March 8, 1983. American Mineralogist 70, 433-435.

Haapala, I. 2009. Maankamaran tutkijat maailmalla, In: Löytönen, M. (ed.) Suomalaiset tutkimusmatkat. Suomalaisen Kirjallisuuden Seura, Helsinki, pp. 119-185.

Haapala, I. 2011. Th.G. Sahama's (1910-1983) volcanological and mineralogical studies in Africa: Part II. Minerals of granitic pegmatites and other mineral occurrences of eastern and southern Africa. Bulletin of the Geological Society of Finland 83, 57-70.

Hertogen, J., Vanderberghe, L. \& Namegabe, M.R. 1985. Geochemical evolution of the Nyiragongo volcano (Virnga, Western Africa Rift, Zaire). Bulletin of the Geological Society of Finland 57, 21-35.

Holmes, A. 1942a. A suite of volcanic rocks from south-west Uganda containing kalsilite (a polymorph of KAlSiO4). Mineralogical Magazine 41, 197-217.

Holmes, A. 1942b. A heteromorph of venanzite. Geological Magazine 74, 225-232.

Hytönen, K. 1959. On the petrology and mineralogy of some alkaline volcanic rocks of Toror Hills, Mt. Moroto, and Morulinga in Karamoja, northeastern Uganda. Bulletin de la Commission géologique de Finlande 184, 1-64.

Lehtinen, M. \& Sahama, Th.G. 1982. A note on the feldspars in the granitic xenoliths of the Nyiragongo magma. Bulletin of Volcanology 44, 451-454.

Neuvonen, K.J. 1956. Minerals of the Katungite flow. Bulletin de la Commission géologique de Finlande 172, 1-7.

Neuvonen, K.J. 1985. Thure Georg Sahama in memoriam, 14.10.1910-8.3.1983, with bibliography by M. Lehtinen. Bulletin of the Geological Society of Finland 57, 3-9.

Platz, T., Foley, S.F. \& Andre, L. 2004. Low-pressure fractionation of the Nyiragongo volcanic rocks, Virunga Province, D. R. Congo. Journal of Volcanology and Geothermal Research 136, 269-295.

Rittmann, A. (with contributions by Gottini,v., Hewers, W., Stengelin, R. \& Pichler, H.) 1973. Stable mineral assemblage of igneous rocks. A method of its calculation. Springer Verlag, Heidelberg.

Rogers, N.W., James, D., Kelley, S.P. \& De Mulder, M. 1998. The generation of potassic lavas from the eastern Virunga Province, Rwanda. Journal of Petrology 39, 1223-1247.

Sahama, Th.G. 1953a. Mineralogy and petrology of a lava flow from Mt. Nyiragongo, Belgian Congo. Annales Academiae Scientiarum Fennicae, Series A, III, 35, 1-25.

Sahama, Th.G. 1953b. Parallel growth of nepheline and microperthitic kalsilite from North Kivu, Belgian Congo. 
Annales Academiae Scientiarum Fennicae, Series A, III, $36,1-18$.

Sahama, Th.G. 1954. Mineralogy of mafurite. Bulletin de la Commission géologique de Finlande 166, 21-28.

Sahama, Th.G. 1957. Complex nepheline-kalsilite phenocrysts in Kabfumu lava, Nyiragongo area, North Kivu in Belgian Congo. Journal of Geology 65, 515-526.

Sahama, Th.G. 1960. Kalsilite in lavas of Mt. Nyiragongo (Belgian Congo). Journal of Petrology 1, 146-147.

Sahama, Th.G. 1961. Thermal metamorphism of the volcanic rocks of Mt. Nyiragongo (Eastern Congo). Bulletin de la Commission géologique de Finlande 196, 151-174.

Sahama, Th.G. 1962a. Order-disorder in natural nepheline solid solutions. Journal of Petrology 3, 65-81.

Sahama, Th.G. 1962b. Petrology of Mt. Nyiragongo: A review. Transactions of the Edinburgh Geological Society 19, 128.

Sahama, Th.G. 1966. Polygonal growth of beryl. Bulletin de la Commission géologique de Finlande 222, 31-42.

Sahama, Th.G. 1967. Iron content of melilite. Bulletin de la Commission géologique de Finland 229, 17-28.

Sahama, Th.G. 1968a. Mineralogical composition of the Nyiragongo rocks. Geologische Rundschau 57, 904-914.

Sahama, Th. G. 1968b. Why is Mt. Nyiragongo a volcano of outstanding mineralogical and petrological interest? Académie Royale des Sciences d'Outre-Mer, Bulletin des Séances (Bruxelles) 1968-2, 564-573.

Sahama, Th.G. 1973. Evolution of the Nyiragono magma. Journal of Petrology 14, 33-48.

Sahama, Th.G. 1975. A note on crystal morphology of melilite. Contributions to Mineralogy and Petrology 51, 135-138.

Sahama, Th.G. 1976. Compositions of clinopyroxene and melilite in the Nyiragongo rocks. Garnegie Institution in Washington, Year Book 75 (1975-1976), 585-591.

Sahama, Th.G. 1978. The Nyiragongo main cone. Musée Royale de l'Afrique Centrale. Annales Série in-8, 81, 1-88.

Sahama, Th.G. \& Hytönen, K. 1957a. Götzenite and combeite, two new silicate minerals from the Belgian Congo. Mineralogical Magazine 31, 503-510.

Sahama, Th.G. \& Hytönen, K. 1957b. Kirschsteinite, a natural analogue of synthetic iron monticellite, from the Belgian Congo. Mineralogical Magazine 31, 698-699.

Sahama, Th.G. \& Hytönen, K. 1958. Calcium-bearing magnesium-iron olivines. American Mineralogist 43, 862871.
Sahama, Th. G. \& Hytönen, K. 1959. Delhayelite, a new silicate from the Belgian Congo. Mineralogical Magazine 32, 69.

Sahama, Th.G. \& Lehtinen, M. 1968a. Infrared absorption of melilite. Bulletin de la Commission géologique de Finlande 229, 29-40.

Sahama, Th.G. \& Meyer, A. 1958. Study of the volcano Nyiragongo. A progress report. Institut des Parcs Nationaux du Congo Belge, Mission d'Etudes Vulcanologiques, Fasc. 2, 1-85.

Sahama, Th.G., Neuvonen, K.J. \& Hytönen, K. 1956. Determination of the composition of kalsilites by an Xray method. Mineralogical Magazine 31, 200-208.

Sahama, Th.G., Siivola, J. \& Rehtijärvi, P. 1973. Andremeyerite, a new barium iron silicate from Nyiragongo, Zaire. Bulletin of the Geological Society of Finland 45, 1-8.

Sahama, Th.G. \& Smith, J.V. 1957. Trikalsilite, a new mineral. American Mineralogist 42, 286.

Sahama, Th. G. \& Wiik, H.B. 1952. Leucite, potash nepheline, and clinopyroxene from volcanic lavas from southwestern Uganda and adjoining Belgian Congo. American Journal of Science 250-A (Bowen Volume), 457-470.

Simmons, W.B. Jr. \& Peacor, D.R. 1972. Refinement of the crystal structure of a volcanic nepheline. American Mineralogist 57, 1711-1719.

Smith, J.V. \& Sahama, Th.G. 1954. Determination of the composition of natural nephelines by an X-ray method. Mineralogical Magazine 30, 439-440.

Streckeisen, A. 1967. Classification and nomenclature of igneous rocks. Neues Jahrbuch für Mineralogie, Abhandlungen 107, 144-240.

Tait, K.Y., Sokolova, E. \& Hawthorne, F.C. 2003. The crystal chemistry of nepheline. Canadian Mineralogist 41, 6170.

Tazieff, H. 1984. Recent activity at Nyiragongo and lava lake occurrences. Bulletin of the Geological Society of Finland 57, 11-19.

Thonnard, R.L. \& Denaeyer, M.E. 1965. Carte volcanologique des Virunga, feuille n1, groupe occidental. Centre National de Volcanologie (Belgique), publication n. 32.

Vollmer, R., Nixon, P.H. \& Condliffe, E. 1985. Petrology and geochemistry of a $U$ and $T h$ enriched nephelinite from Mt. Nyiragongo, Zaire: Its bearing on ancient mantle metasomatism. Bulletin of the Geological Society of Finland 57, 37-46. 